\title{
УДК 351.82:338.24
}

DOI https://doi.org/10.32840/pdu.2021.2.22

\section{В. В. Мареніченко}

кандидат наук з державного управління, доцент, доцент кафедри публічного управління та права КЗВо «Дніпровська академія неперервної освіти» Дніпропетровської обласної ради

М. М. Хитько

кандидат наук з державного управління, доцент, доцент кафедри публічного управління та права КзВо «Дніпровська академія неперервної освіти» Дніпропетровської обласної ради

Ю. О. Ліснєвська

кандидат наук з державного управління, доцент, доцент кафедри публічного управління та права КЗВО «Дніпровська академія неперервної освіти» Дніпропетровської обласної ради

\section{СТРАТЕГІЧНІ ПІДХОДИ ДО ДЕРЖАВНОГО РЕГУЛЮВАННЯ ТУРИЗМУ НА МІСЦЕВОМУ ТА РЕГІОНАЛЬНОМУ РІВНЯХ}

Визначено актуальність стратегічного управління та застосування програмно-цільового підходу у державному регулюванні галузі туризму. Стратегічні підходи до державного регулювання туризму слід розглядати через призму програмно-цільового підходу. У ракурсі цього питання важливим стає переміщення акценту з національного на регіональний і місцевий рівні регулювання галузі туризму, в основі чого лежить міжмуніципальне співробітництво. Охарактеризовано переваги міжмуніципального співробітництва у галузі туризму: територіальні громади зможуть об'єднувати свої ресурси (створення туристичних кластерів); здатність залучати приватні кошти та інвестиції, брати участь у проектах публічного приватного партнерства; підвищення рівня довіри у іноземних донорів і партнерів у процесі реалізації окремих проектів розвитку; розробку та реалізацію проектів, які одночасно можуть реалізуватися на території декількох територіальних громад і отримання ними вигоди одночасно. Визначено інформаційну основу проектів розвитку туризму на місцевому рівні, зокрема стратегії місцевого розвитку та просторові програми. Визначено основні напрями у розвитку туристичної сфери згідно зі «Стратегією розвитку туризму та курортів на період до 2026 р.» в Україні, зокрема створення конкурентоспроможного національного туристичного продукту на засадах системної маркетингової діяльності та системне підвищення якості інфраструктури курортів і рекреаційних територій. Визначено, що стратегічним підходом до державного регулювання туризму на місцевому і регіональному рівнях $\epsilon$ механізми стимулювання інвестицій у цій сфері. Для стимулювання інвестицій слід вжити низку заходів у: зниженні рівня державного регулювання комерційної діяльності та забезпеченні стабільності відповідного нормативно-правового поля; удосконаленні норм щодо реалізації майнових прав; удосконаленні діяльності інститутів корпоративного управління; сприянні розвитку ринку капіталу, насамперед банківського сектору, ринків акцій і страхових послуг; зменшенні податкового навантаження на бізнес; забезпеченні стабільного політичного середовища; створенні позитивного іміджу та туристичного бренду України.

ключові слова: громада, державне регулювання, розвиток, стратегічне управління, туризм.

Постановка проблеми. Розвиток науково-технологічного прогресу та доступність подорожей зумовили розви- ток туризму, який стрімко розвивається останні десятиліття та належить до галузі, яка має великі перспективи. Стратегічне

() Мареніченко В. В., Хитько М. М., Ліснєвська Ю. О., 2021 
значення для розвитку туризму відіграє не тільки держава, але і місцеві органи самоврядування та територіальні громади. За умов конкуренції вони повинні не тільки вирішувати нагальні питання, але і створювати передумови для сталого розвитку. Це можливо за рахунок реалізації стратегічних рішень, які будуть продуманими, виваженими, амбітними й інноваційними, оскільки жодна територія сьогодні не $\epsilon$ економічним островом. Країни, регіони, міста, села розташовані у єдиному просторі та належать до глобальної економічної системи. Ефективне управління місцевим розвитком пов'язане з розумінням світових тенденцій і використанням закономірностей глобальної економіки на користь розвитку громади. XXI сторіччя визнано епохою розвитку територій, створення агломерацій і формування нових «точок росту», а одним із перспективних напрямів розвитку як сільських територій, так і міських агломерацій є туризм.

Аналіз останніх досліджень і публікацій. Дослідженню формування стратегії розвитку туризму, механізмів і стратегічних підходів у державному регулюванні цієї сфери, державної стратегії розвитку туристичної галузі присвячено праці таких відомих вчених, як Н. Бедрік, О. Лотиш, Т. Лужанська, М. Мальська, Ю. Масюк, К. Роналд, I. Січка, Т. Чичкалюк, Е. Щепанський. Тим не менш, актуальними та недостатньо дослідженими залишаються питання муніципального співробітництва, розвитку туризму на регіональному та місцевому рівнях із застосуванням стратегічних підходів до державного регулювання.

Мета статті - визначення стратегічних підходів до державного регулювання туризму на місцевому і регіональному рівнях.

Виклад основного матеріалу. Територіальні громади мають великі можливості не тільки розвитку, але і перетворення депресивних територій у привабливі території шляхом створення туристичних дестинацій і збереження пам'яток культури та народних промислів. У зв'язку 3 цим важливого значення набуває розробка проектів розвитку. За умов децентралізації проекти розвитку є інструментами, що дозволяють згуртувати громаду, вирішити стратегічні проблеми та створити передумови для підвищення комфортності проживання на певній території та можливості задовольняти життєво важливі інтереси.

Це зумовлює зростання ролі та значення стратегічного планування розвитку територіальних громад на основі міжмуніципального співробітництва у галузі туризму.

За сучасних умов інформатизації, глобалізації економіки, гіперконкуренції стає очевидним, що важливим чинником функціонування будь-якої господарської системи $\epsilon$ ії̈ забезпечення адекватною управлінською системою. Одним із передових підходів до управління за умов всезагального динамізму, непередбачуваності та мінливості бізнес-середовища визнане стратегічне управління [3].

На думку Т. Лужанської, сьогодні $\epsilon$ актуальним застосування елементів стратегічного управління за оптимального його поєднання з методами та формами оперативного (короткострокового) управління [2]. Це дійсно має сенс у контексті мінливих і швидкозмінних умов пандемії COVID-19, особливо в галузі туризму.

За дослідженнями Т. Чичкалюк, для розвитку туристичної галузі слід застосовувати програмно-цільовий метод, який використовує сукупність прийомів і засобів дії на суб'єктів господарювання сфери рекреації та туризму, з орієнтацією на постановку цілей і завдань і конкретизацію виконавців, забезпечення контролю за кінцевим результатом [6].

I. Щепанський у своїх працях зазначає, що програмно-цільовий метод державного регулювання рекреаційно-туристичної сфери здійснюється через використання прямих заходів управління процесами та суб'єктами та побічних заходів регулювання ринкових відносин [7].

Таким чином, стратегічні підходи до державного регулювання туризму слід розглядати через призму програмно-цільового підходу, тож важливим стає переміщення акценту з національного на регіональний і місцевий рівні регулювання галузі туризму, в основі чого лежить міжмуніципальне співробітництво.

Міжмуніципальне співробітництво у галузі туризму дозволяє отримати такі переваги: 
- територіальні громади зможуть об'єднувати свої ресурси (створення туристичних кластерів);

- більший за кількістю споживачів «ринок послуг», що сприятиме зменшенню витрат на надання послуг;

- здатність залучати приватні кошти та інвестиції, брати участь у проектах публічного приватного партнерства;

- підвищення рівня довіри у іноземних донорів і партнерів у процесі реалізації окремих проектів розвитку;

- можливість надавати якісні адміністративні послуги та підвищувати рівень прозорості ведення бізнесу;

- розробка та реалізація проектів, які одночасно можуть реалізуватися на території декількох територіальних громад і отримання ними вигоди одночасно;

- створення нових «мультикультурних» проектів щодо розвитку окремих територій;

- реалізація спільних заходів щодо зменшення негативного впливу таких факторів: нерозвиненої транспортної інфраструктури або її низької якості, відсутності почуття безпеки у людей і територіальної нерівності; зростаючої бідності та безробіття, загрози техногенних катастроф і зменшення біорізноманітності, деградації ґрунтів, браку водних ресурсів, незадовільної утилізації твердих, небезпечних і токсичних відходів, обмеженого доступу до безпечних джерел енергії тощо [1].

Наведені негативні фактори можливо нейтралізувати саме за рахунок реалізації інтегрованого стратегічного підходу.

Інформаційною основою проектів розвитку туризму на місцевому рівні $\epsilon$ :

- стратегії місцевого розвитку, спрямовані на реалізацію заходів щодо сприяння розвитку підприємництва, поліпшення інвестиційного клімату, забезпечення соціальних потреб населення, підвищення рівня його життя;

- просторові програми (Генеральні плани населених пунктів).

Генеральний план населеного пункту це основний містобудівний проект, який визначає принципи організації території щодо її розвитку, планування, забудови з урахуванням державних, приватних і громадських інтересів. Оскільки на тери- торії знаходяться туристичні та туристично-рекреаційні ресурси, які можуть бути під охороною держави або ЮНЕСКО, мати важливе значення для нації та світової громади, то стратегічну роль відіграють саме генеральні плани населених пунктів.

Кінцевий результат полягає у створенні комфортних умов для праці, побуту і відпочинку, спектр яких у змозі задовольнити економічні, соціальні та культурно-побутові потреби жителів і задовольнити їх життєво важливі інтереси, зберегти унікальність території та її окремих об'єктів (пам'яток культури національного та світового значення). Це стає можливим за рахунок реалізації принципів сталого розвитку, де стратегічний план $є$ документом, який дозволяє визначити «вузькі місця» та першочергові завдання (проблеми), котрі потребують вирішення.

Слід зазначити, що у світовій практиці вже існують успішні приклади міст, які мають стратегії сталого розвитку, зокрема Оттава (Стратегія управління ростом «Оттава - 2020»), Канберра (План розвитку міста на 30 років, що включає Соціальний план, Територіальний план і План економічного розвитку), Мельбурн (Стратегічний план розвитку Мельбурна до 2030 р.) [5].

Наприклад, Концепція забудови Берліна зосереджена на створенні «міста коротких шляхів» шляхом підвищення будівельної щільності до рівня традиційних європейських міст. Це вимагає «зворотної забудови» занадто широких автотрас із метою підвищення якості життєвого рівня та перебування у центрі міста. Завдяки об'єднанню в єдину мережу електрички, метро, трамваїв, автобусів і розширенню мережі маршрутів пасажирського транспорту стала можливою реалізація постанови берлінського Сенату, відповідно до якої $80 \%$ усіх пасажирських перевезень у центрі Берліна будуть здійснюватися муніципальним пасажирським транспортом, а $20 \%$ - автомобілями.

16 березня 2017 р. Кабінетом Міністрів України було видано розпорядження «Про схвалення Стратегії розвитку туризму та курортів на період до 2026 р.». «Метою реалізації Стратегії $\epsilon$ формування сприятливих умов для активізації розвитку сфери 
туризму та курортів згідно з міжнародними стандартами якості та з урахуванням європейських цінностей, перетворення ії на високорентабельну, інтегровану у світовий ринок конкурентоспроможну сферу, що забезпечує прискорення соціальноекономічного розвитку регіонів і держави загалом, сприяє підвищенню якості життя населення, гармонійному розвитку і консолідації суспільства, популяризації України у світі» [4].

«Основними стратегічними цілями розвитку сфери туризму та курортів з урахуванням сучасного стану і тенденцій розвитку України на період до 2026 р. є:

- створення конкурентоспроможного національного туристичного продукту на засадах системної маркетингової діяльності;

- забезпечення ефективного та комплексного (економічного, соціального, екологічного й інноваційного) використання наявного туристичного та курортно-рекреаційного потенціалу шляхом розв'язання проблеми рекреаційного природокористування й охорони навколишнього природного середовища й удосконалення територіальної структури сфери туризму та курортів;

- системне підвищення якості інфраструктури курортів і рекреаційних територій шляхом виконання комплексної програми поетапного вдосконалення матеріально-технічної бази з використанням можливостей кластерних моделей, державно-приватного партнерства та соціального замовлення;

- удосконалення інформаційної інфраструктури рекреаційних і туристичних послуг шляхом створення центрів туристичної інформації та популяризації туристичних продуктів;

- забезпечення відповідності ціни та якості туристичних продуктів шляхом створення умов для оптимізації структури діяльності суб'єктів малого та середнього бізнесу у сфері туризму» [4].

За результатами реалізації Стратегії заплановано досягнення деяких контрольних показників у розвитку туристичної сфери. Так, до 2026 р. заплановано досягнення більшої кількості туристів-іноземців, які в їжджають до України, у 2,5 рази, збільшення кількості суб'єктів туристичної діяль- ності у 5 разів, обсягів надходжень у місцеві бюджети від сплати туристичного збору й обсягів надходжень до зведеного бюджету від діяльності суб'єктів туризму - у 10 разів, кількості робочих місць - у 5 разів.

Сучасна практика інвестування допускає використання спеціальних механізмів залучення коштів у туристичну сферу. Найдієвіші з них проявляються у:

- формуванні спеціальних зон пріоритетного розвитку туристичної сфери, рекреації зі специфічним режимом для найбільшого економічного сприяння розвитку бізнесу й інвестиційного залучення коштів;

- формуванні на територіях міст (регіонів) спеціалізованих компаній чи агентств із розвитку, які займаються реалізацією інвестиційних проектів у сфері розвитку туристичної інфраструктури.

Створення стратегії інвестиційного розвитку туристичної сфери слід виконувати на базі принципів:

- професійного підходу до впровадження рекламних кампаній і проведення необхідних маркетингових досліджень;

- чіткого розподілу функцій і ролей між сторонами, які беруть участь у роботі з розвитку інфраструктури туризму.

Таким чином, реалізація стратегічної основи державної політики у сфері туризму в Україні зі стабільним зростанням доходів від цієї сфери потребує залучення інвестицій. Хоча Україна і має значний потенціал і всі необхідні умови для розвитку країни в рамках пріоритетності туризму, ми суттєво відстаємо від провідних країн світу за рівнем розвитку інфраструктурних об'єктів туризму та якості послуг із туризму.

Ця проблема висвітлена у Стратегії розвитку туризму та курортів на період до 2026 р., де запропоновано низку заходів, спрямованих на ії подолання. Сучасний стан розвитку туризму потребує активної політики у залученні прямих іноземних і державних інвестицій. Законодавче поле, котре регулює інвестиційну діяльність в Україні, зараз знаходиться лише на етапі вдосконалення й оновлення, що відкриває нові горизонти для залучення інвестицій і нові перспективні можливості розвитку.

Сталий ріст потребує інвестицій, тобто збільшення основного та людського капіталу. За умов сучасного стану економіки 
приватний бізнес акумулює основний капітал для реалізації потенціалу майбутнього виробництва. Інвестиції в інфраструктурне забезпечення, тобто у транспортування та мережеві поставки, такі як передача та розподіл енергетичних ресурсів, телекомунікацій, водовідведення та санітарії, часто здійснюються за рахунок державного бюджету, але за участі приватного бізнесу. Крім цього, довгостроковий ріст вимагає втілення технічного прогресу у нових сферах.

Для того, щоб туристичний бізнес при зарубіжних інвестиціях сприяв розвитку національної економіки, необхідно і будівництво, і експлуатацію туристичних центрів здійснювати у тісному взаємозв'язку з місцевими ресурсами, такими як:

- місцева робоча сила;

- місцеві матеріали для будівництва та технічного оснащення туристичного комплексу;

- продукція місцевого сільськогосподарського виробництва.

Інакше кажучи, для того, щоб розвиток туризму позитивно впливав на економіку, туристичний бізнес необхідно створювати з урахуванням необхідності та можливості максимального використання місцевих природних і кадрових ресурсів.

Якщо ж основна частина капіталу буде залишатися в руках зарубіжних фірм, то розвиток іноземного туристичного обміну може призвести до збільшення залежності національної економіки від іноземного капіталу. Якщо ж туристичний бізнес будувати не за рахунок внутрішніх коштів, а за рахунок тільки іноземного капіталу, із залученням іноземних фахівців і великих зарубіжних фірм, то розвиток туризму може привести до підвищення цін на товари та послуги в зв'язку зі згортанням місцевого виробництва.

Висновки і пропозиції. Визначено, що стратегічним підходом до державного регулювання туризму на місцевому і регіональному рівнях $€$ механізми стимулювання інвестицій у цій сфері.
Для стимулювання інвестицій слід виконати низку заходів у таких напрямах:

- зниженні рівня державного регулювання комерційної діяльності та забезпеченні стабільності відповідного нормативно-правового поля;

- удосконаленні норм щодо реалізації майнових прав;

- удосконаленні діяльності інститутів корпоративного управління;

- сприянні розвитку ринку капіталу, насамперед банківського сектору, ринків акцій і страхових послуг;

- зменшенні податкового навантаження на бізнес;

- забезпеченні стабільного політичного середовища;

- створенні позитивного іміджу та туристичного бренду України.

\section{Список використаної літератури:}

1. Локальний туризм в умовах сьогодення. URL: http://hmrayrada.gov.ua/ news/2020-07-01-03/.

2. Лужанська Т.Ю. Стратегії розвитку регіональних туристичних дестинацій. Науковий вісник Мукачівського державного університету. 2014. № 2 (2). С. 175-180.

3. Масюк Ю.О. Стратегічне управління розвитком туризму в Україні : дис. ... канд. економ. наук : 08.00.03 / Львів. нац. ун-т ім. І. Франка МОНУ. Львів, 2017.318 с.

4. Стратегія розвитку туризму та курортів на період до 2026 р., схвалена Розпорядженням Кабінету Міністрів України від 16 березня 2017 р. № 168-р. Офіційний Вісник України. 2017. № 26. С. 86.

5. Успешные истории. Комиссия ООН по устойчивому развитию. URL: http://www. un.org/ru/ga/habitat/.

6. Чичкалюк Т. Застосування програмноцільового методу як ефективного інструменту управління розвитком рекреаційно-туристичного регіону. Вісник Черкаського університету. 2015. № 12 (345). С. 133-136.

7. Щепанський Е. Програмно-цільовий метод державного регулювання розвитком туристично-рекреаційної сфери. Університетські наукові записки. 2017. № 64. C. $10-22$.

\footnotetext{
Marenichenko V., Khytko M., Lisnievska Yu. Strategic approaches to state regulation of tourism at local and regional levels

The relevance of strategic management and application of program-target approach in state regulation of tourism is determined. Strategic approaches to state regulation of tourism should be considered through the prism of a program-targeted approach. From
} 
the perspective of this issue, it is important to shift the emphasis from the national to the regional and local level of regulation of the tourism industry, which is based on intermunicipal cooperation. The advantages of inter-municipal cooperation in the field of tourism are described, among which the following should be singled out: territorial communities will be able to pool their resources (creation of tourist clusters); ability to attract private funds and investments, participate in public-private partnership projects; increasing the level of trust of foreign donors and partners in the implementation of individual development projects; development and implementation of projects that can be implemented simultaneously in several territorial communities and benefit from them simultaneously. The information base of tourism development projects at the local level, in particular, local development strategies and spatial programs, is determined. The main directions in the development of tourism in accordance with the "Strategy for tourism and resorts for the period up to 2026" in Ukraine, in particular, the creation of a competitive national tourism product on the basis of systematic marketing activities and systematic improvement of infrastructure of resorts and recreational areas. As a result of the researches it is determined that the strategic approach to the state regulation of tourism at the local and regional levels is the mechanisms of stimulating investments in this sphere. To stimulate investment, the following number of measures should be taken to: reduce the level of state regulation of commercial activities and ensure the stability of the relevant regulatory framework; improving the rules for the implementation of property rights; improving the activities of corporate governance institutions; promoting the development of the capital market, primarily the banking sector, stock markets and insurance services; reducing the tax burden on business; ensuring a stable political environment; creating a positive image and tourist brand of Ukraine.

Key words: community, state regulation, development, strategic management, tourism. 